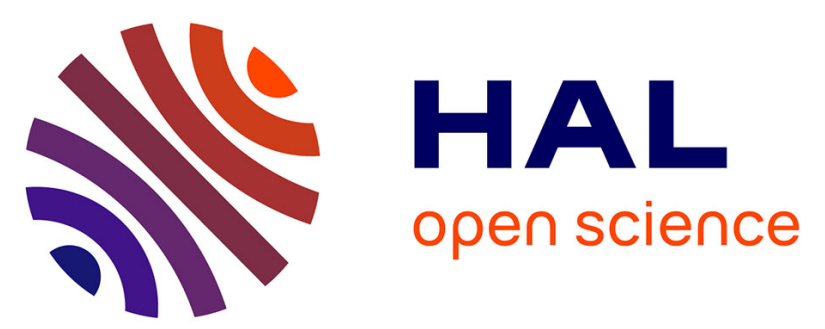

\title{
IMPACT FRACTURE TOUGHNESS TEST OF CERAMIC REINFORCED METALS
}

S. Takahashi, K. Kishimoto, S. Aoki

\section{To cite this version:}

S. Takahashi, K. Kishimoto, S. Aoki. IMPACT FRACTURE TOUGHNESS TEST OF CERAMIC REINFORCED METALS. Journal de Physique IV Proceedings, 1991, 01 (C3), pp.C3-769-C3-774. 10.1051/jp4:19913108 . jpa-00249910

\section{HAL Id: jpa-00249910 https://hal.science/jpa-00249910}

Submitted on 1 Jan 1991

HAL is a multi-disciplinary open access archive for the deposit and dissemination of scientific research documents, whether they are published or not. The documents may come from teaching and research institutions in France or abroad, or from public or private research centers.
L'archive ouverte pluridisciplinaire HAL, est destinée au dépôt et à la diffusion de documents scientifiques de niveau recherche, publiés ou non, émanant des établissements d'enseignement et de recherche français ou étrangers, des laboratoires publics ou privés. 
Colloque C3; suppl. au Journal de Physique III, Vo1. 1, octobre 1991

\title{
IMPACT FRACTURE TOUGHNESS TEST OF CERAMIC REINFORCED METALS
}

\author{
S. TAKAHASHI, K. KISHIMOTO and S. AOKI
}

Faculty of Engineering, Department of Mechanical Engineering Science, Tokyo Institute of Technology, o-okayama, Meguro-ku, Tokyo 152, Japan

\begin{abstract}
Résumé: Des tests de résilience à la rupture par impact ont été réalisés à température ambiante et à $200^{\circ} \mathrm{C}$ en utilisant un système d'impact par flexion un point. Le module $\mathrm{d}^{\prime}$ Young et le coefficient de Poisson du matériau testé ont été mesurés pour chaque température d'essai pour déterminer de manière précise le facteur d'intensité de contrainte. La constante élastique du matériau est mesurée pour calculer le facteur d'intensité de contrainte avec la correction de la zone plastique. On a aussi effectué des essais de résilience à la rupture en statique pour les comparer aux données en dynamique. On a trouvé que la résilience à la rupture par impact des matériaux testés diminue avec l'augmentation de température et, de plus, la résilience à la rupture croît. lorsque la vitesse de chargement augmente.

Abstract-Impact frature toughness tests are performed at room temperature and $200^{\circ} \mathrm{C}$ by using the one-point-bending impact system. Young's modulus and Poisson's ratio of the tested materials are measured at each test temperature to determine the stress intensity factor accurately. Yield stress of the tested materials is measured to calculate the stress intensity factor with plastic zone correction. Also static fracture toughness tests are performed to compare the dynamic with static fracture toughness data. It is found that the impact fracture toughness of the tested materials decreases with increasing test temperature and, furthermore, that the fracture toughness increases with increasing loading rate.
\end{abstract}

\section{INTRODUCTION}

Many ceramic materials exhibit high temperature strength as well as heat resistance, oxidation resistance and wear resistance, but they show a low toughness. $0 \mathrm{n}$ the other hand, metals show a high toughnesses, but low strength values as well as low heat resistance, oxidation resistance and wear resistance. Thus, it has been tried to combine a ceramic material and a metal with the aim to develop a new material that is characterized by the positive properties of each of the individual materials. Knowledge on the fracture behavior of this composite material under static and impact loading is required to obtain a suitable combination of a ceramic material and a metal. Unfortunately, only a few investigations have been published on the fracture behavior of composite materials so far.

In the present investigation, the static fracture toughness $K_{\mathrm{I} c}$ and the inpact fracture toughness $K_{I d}$ of alumina-fiber/aluminium and alumina-powder/aluminium is measured at room teperature and at $200^{\circ} \mathrm{C}$.

\section{TEST MATERIALS AND TEST SPECIMENS}

The tested materials are alumina-fiber/aluminium and alumina-powder / aluminium. Mechanical properties at room temperature are presented in Table 1. The test specimen is basically of the Charpy type(width $B=6 \mathrm{~mm}$, height $W=8 \mathrm{~mm}$ and length $S=50 \mathrm{~mm})$. The specimen has a pre-fatigue crack, the crack length a is $a / W=0.7$. 


\section{FRACTURE TOUGHNESS TEST}

\subsection{One-point-bending impact tester}

The impact fracture toughness $K_{I d}$, is measured in a so called one-pointbending impact tester[1]. The general arrangement of the impact tester is shown in Fig. 1. The impact test involves only a central loading of the specimen with free, i.e. unsupported ends. A specimen ith a pre-fatigue crack is suspended in an infrared image furnace by two thin ceramic threads cemented onto the end surfaces of the specimen. The specimen then is heated up to the specified temperature.

Table 1 Mechanical properties (at room temperature)

\begin{tabular}{|c|c|c|}
\hline & $\mathrm{Al}_{2} \mathrm{O}_{3} \mathrm{FIBER} / \mathrm{Al}$ & $\mathrm{Al}_{2} \mathrm{O}_{3} \mathrm{PONDER} / \mathrm{Al}$ \\
\hline Young's modulus ( $\left.\mathrm{GPa}^{2}\right)$ & 97.8 & 149.4 \\
\hline Density $\left(\mathrm{g} / \mathrm{cm}^{3}\right)$ & 2.83 & 3.15 \\
\hline Poisson's ratio & 0.31 & 0.37 \\
\hline Fracture toughness $\left(\mathrm{MPaq}^{1 / 2}\right)$ & 12.1 & 11.6 \\
\hline
\end{tabular}

The impact force is provided by a falling steel cylinder. A pair of semiconductor strain gauges are cemented onto the cylindrical surface to measure the stress wave history and hence to deternine the impact force $F(t)$. Since the value of $K_{\mathrm{I}}(t)$ reaches its maximum value during the period when the specimen ends jump up, the specimen fractures with both ends free from constraint. The length of the falling cylinder and the location where the strain gauges are cemented are designed so that the strain gauges remain outside of the furnace during and after the impact. Furthermore, the stress waves reflected at the upper surface of the cylinder will not arrive at the location of the strain gauges during the contact period of the cylinder and the specimen. The instrumentation system employed is schematically represented in Fig. 1. The time variation of $K_{I}(t)$ is computed by a simple formula [1], which will be described in the following section.

3.2 Simple formula for dynaric stress intensity factor of one-point-bendig specimen

The dynamic stress intensity factor $K_{1}(t)$ is computed by the following simple formula from the impact force $F(t)[1][2]$.

$$
\begin{aligned}
K_{\mathrm{I}}(t)=k_{\mathrm{II}} & \frac{E I}{S^{2}} \sum_{\mathrm{m}=1}^{\infty} \frac{Y_{\mathrm{Fm}}(\xi)\left|{ }_{\xi=1 / 2} \cdot Y_{\mathrm{Fm}}^{\#}(\xi)\right| \xi=1 / 2}{\omega_{\mathrm{F}_{\mathrm{II}}} W_{\mathrm{Fm}_{\mathrm{m}}} S} \\
& \times \int_{0}^{t} F(\tau) \sin \omega_{\mathrm{Fm}}(t-\tau) \mathrm{d} \tau
\end{aligned}
$$

where $E$ is the Young's modulus of the beam, $I$ is the moment of inertia of the cross-section, $S$ is the span length of the beam, $Y_{F_{m}}$ is the characteristic function of the beam, $\xi$ is the coordinate normalized by $S$ along the beam axis with the origin at the left end of the specimen. Prime' represents partial differentiation with respect to $\xi, \omega F_{m}$ is the eigen frequencies of the beam. The constant $k_{\mathrm{m}}$ is assumed to be determined from the static solution. Since it is difficult to perform a static one-point-bend experiment, $k_{\mathrm{m}}$ is determined in reference to the analytical relation between the stress intensity factor and the moment at mid-span of three-point-bend specimen.

3.3 Deternination of impact fracture toughness

For the determination of the $i$ mpact fracture toughness it is necessary to know the time history of the dynamic stress intensity factor $K_{I}(t)$ and the crack intiation time. Usually the crack initiation time is obtained by strain gauge instrumentation of the specimen, however, at high temperatures it is difficult to use strain gauges. Therefore, in this study, a series of impact tests with different 
drop-heights is performed with several specimens. After each impact test the crack surface of the specimen is marked by fatigue loading and the crack surface is observed with use of $S E M$ to investigate the existence of any crack propagation in the test. The impact fracture toughness $K_{1 d}$ is determined from the test data for the minimum drop-height that causes crack propagation.

Typical examples of the time history of the impact force $F(t)$ and those of the time history of the dynamic stress intensity factor $K_{I}(t)$ (computed from the

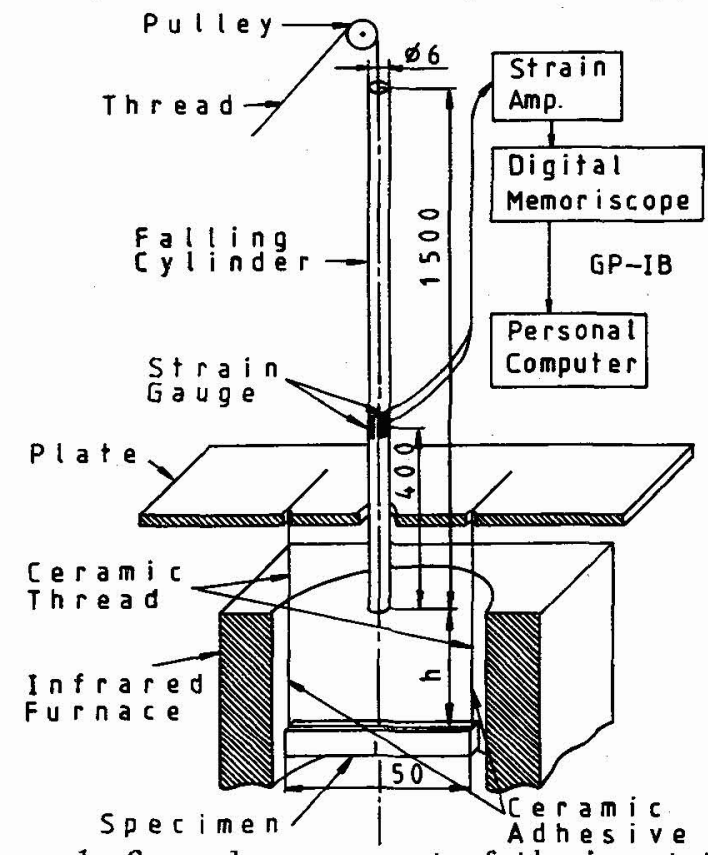

Figure 1. General arrangement of the impact tester

measured impact force data) are shown in Fig. 2(a) and 2(b), respectively. The solid curves represent the results for the specimen that showed crack propagation at the minimum drop-height while the dashed curves apply for a specimen where crack propagation did not occur. It is shown in Fig. 2(a) that the second and third peak of the impact force $F(t)$ in the case when crack propagation did occur (solid curve) are observed later than those when crack propagation did not occur (dashed curve). It seems that crack propagation occurs at that time when the solid curve of the dynanic stress intensity factor $K_{I}(t)$ reaches its first peak. The second and third peak of the impact force are delayed (see Fig. 2(a)), because of the increase of specimen compliance and the decrease of natural frequencies of the specimen with
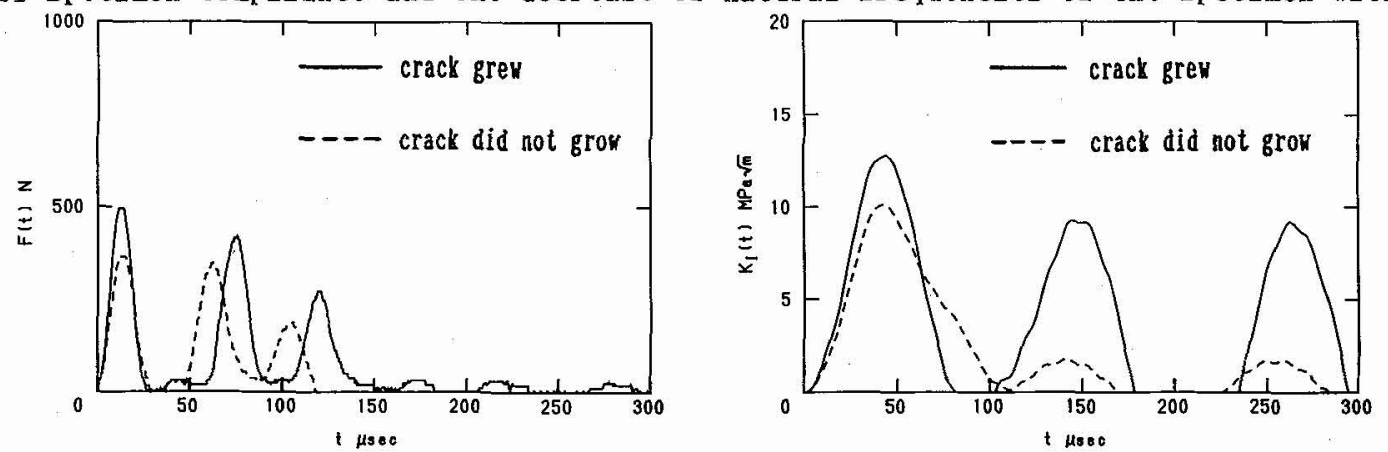

(a) Impact force $F(t)$

(b) Dynamic stress intensity factor $K_{1}(t)$

Figure 2. Time history of impact force and dynamic stress intensity factor (alumina-powder/aluminium:200) 
crack propagation. The impact fracture toughness $K_{I d}$ is determined as maximun value of the first peak of the solid curve of the dynamic stress intensity factor $K_{I}(t)$.

\subsection{Plastic zone correction}

The matrix material of the test materials is aluminiun which is very ductile. It is possible, therefore, that the plastic zone at the crack tip has an influence on the dynamic stress intensity factor. Thus, in addition to the dynanic stress intensity factor without plastic zone correction, $K_{\mathrm{I}}(t)$, the dynamic stress intensity factor with plastic zone correctin, $K_{I}^{*}(t)$, is also calculated. The dynamic stress intensity factor with plastic zone correction, $K{ }_{I}^{*}(t)$, is based on the assumption that the stress distribution surrounding the plastic zone near the crack tip ( $r$ eal crack length is a and plastic zone size is $2 r_{p}$ ) can be approximately represented by the elastic stress distribution surrounding an imaginary crack of length $a^{*}=a+r_{p}$.

Since the plastic zone size $2 r_{0}$ varies during the inpact event, the corrected crack length $a^{*}$ and, therefore, the natural freqencies of the specimen $\omega{ }^{\prime}$ also vary. The corrected crack length $a^{*}$ and the natural frequencies of a specimen $\omega_{\mathrm{Fm}}$ are considered to be constant in a time increment $\Delta t$ and the dynamic stress intensity factor with plastic zone correction $K_{I}^{*}(t)$ is calculated for each time increment $\Delta t$ beginning with the first step[3][4].

The dynamic stress intensity factor of alumina-powder/aluminiun measured at $200^{\circ} \mathrm{C}$ is shown in Fig. 3. Since the stress intensity factor with plastic zone correction $K_{I}^{*}(t)$ is estimated on the basis of a crack length $a^{*}=a+r_{p}$ and the stress intensity factor without plastic zone correction $K_{I}(t)$ on the basis of a crack length $a$, the maximul value of the data with plastic zone correction is a little higher than that of the data without plastic zone correction.

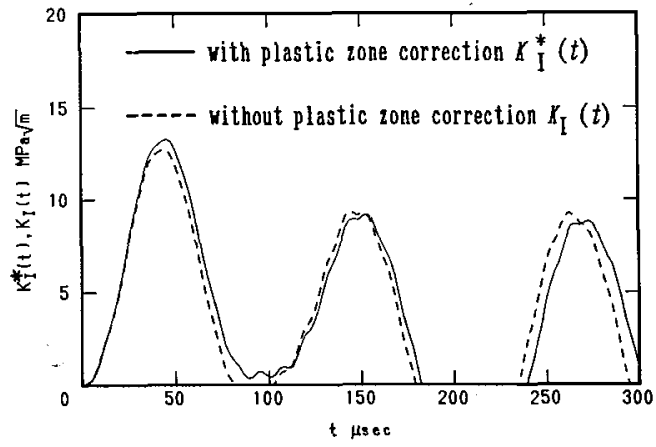

Figure 3. Comparison between $K_{I}^{*}(t)$ and $K_{I}(t)$

Generally, the yield stress increases with increasing loading rate. In the present study, the yield stress is measured by static loading and, therefore, the real yield stress in a dynamic test is higher than the measured one. It is expected, therefore, that the maximum value of the stress intensity factor is in fact between the maximum value of $K_{I}^{*}(t)$ and the maximum value of $K_{I}(t)$.

3.5 Static fracture toughness test

For comparison with the impact fracture toughness data, the static fracture toughness of the test materials is measured at each temperature by means of threepoint-bend experiments. The specimen is loaded at a cross-head speed of $0.5 \mathrm{~mm} / \mathrm{min}$.

\section{EXPERIMENTAL RESULTS AND DISCUSSION}

4.1 Experimental results

The relationship between the measured fracture toughnesses and the loading rate $\dot{K}$ is illustlated in Fig. 4. The loading rate $\dot{K}$ is determined by dividing the fracture toughness by the time to fracture. In both materials, the fracture toughness increases with increasing loading rate. This tendency is stronger at $200{ }^{\circ} \mathrm{C}$ 
than at roon temperature. There is little difference between the data with or without plastic zone correction. The data of alumina ceranic is also illustrated in Fig. 4(a) for reference. The fracture toughness of alumina ceramic is about $1 / 2$ or $1 / 3$ of the fracture toughness of the test materials, furthermore, it slightly increases with increasing loading rate $\dot{X}$.

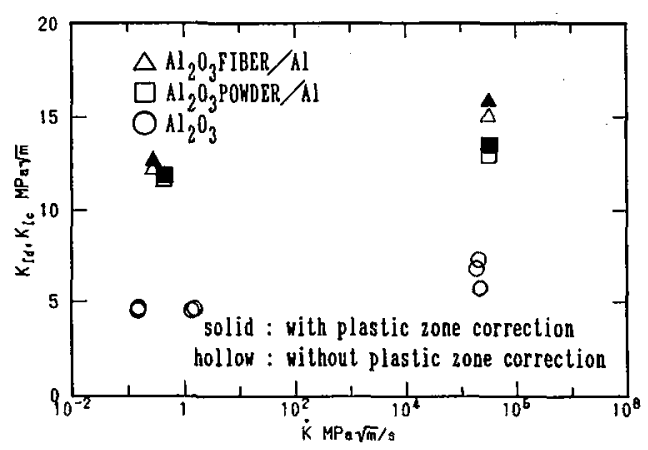

(a) room temperature

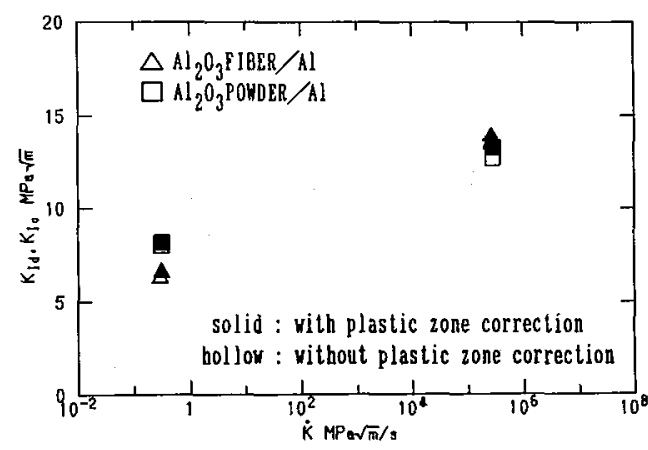

(b) $200^{\circ} \mathrm{C}$

Figure 4. Fracture toughness vs. loading rate

The relationship between fracture toughness and test temperature is shown in Fig. 5. In both materials, the fracture toughness decreases with increasing test temperature. This tendency is stronger for the static fracture toughness $K_{1}$ c than for the inpact fracture toughness $K_{I 0}$. The data of alumina ceramic is also illustrated in Fig. $5(\mathrm{~b})$ for reference. The impact fracture toughness of alumina ceramic is almost constant up to $300^{\circ} \mathrm{C}$.

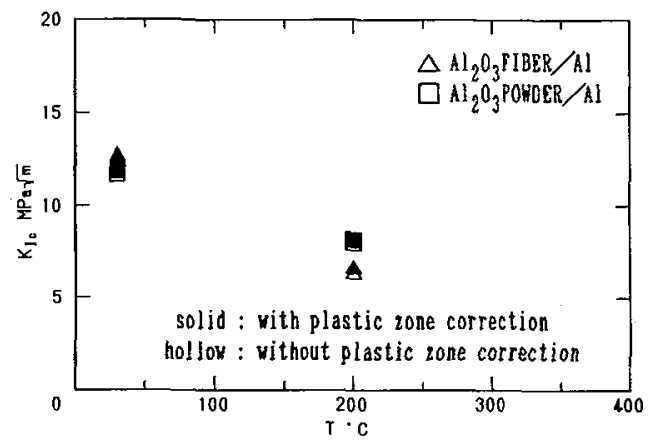

(a) static fracture toughness $K_{\mathrm{I}} \mathrm{c}$

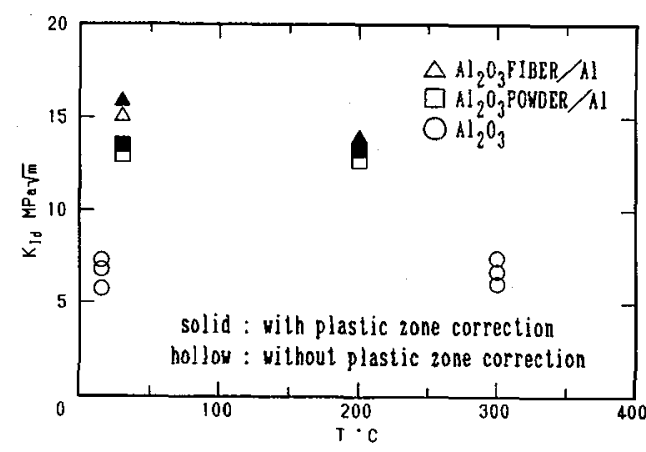

(b) impact fracture toughness $K_{I d}$ vs . testing temperature

\subsection{Discussion}

The observation of the crack propagation sufaces of both materials indicates that many voids around the alumina fiber and alumina powder are produced first which then combine and form big dimples. Thus, the production, growth and combination of voids of the matrix material will play an important role in the crack propagation process. The melting point $\mathrm{T}_{\mathrm{m}}$ of the matrix material aluminiun is $\mathrm{T}_{\mathrm{m}}=660+273=$ $973^{\circ} \mathrm{K}$, creep deformation will occur at $\mathrm{T}_{\mathrm{D}} \doteqdot 0.5 \mathrm{~T}_{\mathrm{m}}=467^{\circ} \mathrm{K}=194^{\circ} \mathrm{C}[5]$. Therefore, it will be of influence near the crack tip in those specinens tested at $200^{\circ} \mathrm{C}$.

The static fracture toughness $K_{1} \mathrm{c}$ at $200^{\circ} \mathrm{C}$ is smaller than the value at roon temperature (shown in Fig. 5(a)). It is speculated that the decrease in the static fracture toughness with increasing test temperature is due to the acceleration of void growth by creep deformation of the matrix materials at high temperatures. On the other hand, the difference between $K_{I d}$ at room temperature and 
at $200{ }^{\circ} \mathrm{C}$ is not as large as that between $K_{I C}$ at room temperature and at $200^{\circ} \mathrm{C}$. Since in impact tests the duration of loading is too short to generate creep deformation at a larger scale, its influence on $K_{I d}$ will be comparatively small. The experimental result shown in Fig.5(b), i.e. $K_{1 d}$ being practically insensible to the test temperature, is qualitatively explained by this interpretation. The experimental result shown in Fig. 4(a) and 4(b), i.e. the increase of fracture toughness with increasing loading rate being more pronounced for $200^{\circ} \mathrm{C}$ than for room temperature, is also qualitatively explained by this interpretation.

As shown in Fig. 4(a), the fracture toughness of alumina ceramic increases with increasing loading rate $\dot{K}$. An attempt is made to explain the dependence of fracture toughness of alumina ceramic on loading rate[6]. It is known that in general the fracture toughness of ductile materials increases with increasing loading rate. This tendency is explained in [7][8] on the basis that the yield stress increases with increasing loading rate $\dot{K}$, which thus will make it difficult to open the crack surface. According to these tendencies, it is speculated that the fracture toughness of the test materials will increase with increasing loading rate $\dot{k}$.

The speculation above does not explain the contribution of alumina-fiber or alumina-powder on the fracture toughness. It seems necessary to correctly modell the fracture mechanism and/or to numerically simulate the fracture process in order to solve this problem.

\section{CONCLUSION}

In the present study, the static fracture toughness $K_{10}$ and the impact fracture toughness $K_{I}$ o of two kinds of alumina/aluminium composite materials are measured at room temperature and at $200^{\circ} \mathrm{C}$. The obtained results are as follows:

(1) As the loading rate increases, the fracture toughness of both alumina-fiber/ aluminium and alumina-powder/aluminium at room temperature and at $200{ }^{\circ} \mathrm{C}$ increases. This tendency is stronger at $200^{\circ} \mathrm{C}$ than at room temperature.

(2) With increasing test temperature $T$, the static fracture toughness $K i c$ and the impact fracture toughness $K_{I d}$ of both alumina-fiber/aluminiun and aluminapowder/aluminium decreases. This tendency is stronger for the static fracture toughness $K_{\text {I }}$ than for the impact fracture toughness $K_{\text {Id }}$.

(3) The above experimental tendencies can qualitatively be explained by taking creep deformation of the matrix material into consideration.

\section{REFERENCES}

[1] SAKATA, M., AOKL, S., KISHIM0T0, K., FUJINO, Y. and AKIBA, T., Measurement of dynamic fracture toughness of ceramic material at elevated temperatures by impact tests with free end bend specimen. J. Soc. Mater. Sci. Japan, 1988, 37, 419, pp910-915.

[2] FUJINO, Y., KISHIMOTO, K., AOKI, S. and SAKATA, M., A simple formula for the dynamic stress intensity factor of an impacted freely-supported bend specimen. Transaction of Jap. Soc. Hech. Eng. Ser. A, 1988, 54, 501, pp1101-1106.

[3] AOKI, S., KURITA, M., KISHIMOTO, K., SAKATA, M. and TAYA, M., Measurement of impact fracture toughness for aluminiumalloys and steel. J. Soc. Mater. Sci. Japan, 1987, 36, 402, pp 274-279.

[4] KISHIMOTO, K., HAYASHI, T., INOUE, H. and SHIBUYA, T., A simple method for evaluating the $J$-integral of an impacted one-point-bend specimen. Japan National Congress of Theoretical and Applied Mechanics, 1990, Preprint, pp55-56.

[5] NOWICK, A.S., On the interpretation of "LOW-TEMPERATURE" recoverly phenomena in cold-worked metals. Acta Met., 1955, 3, pp312-321.

[6] BROCKENBROUGH, J.R., SURESH, S. and DUPFY, J., An analysis of dynamic fracture in microcracking brittle solids. Phil. Mag. A, 1988, 58, 4, pp619-634.

[7] COSTIN, L.S, and DUFPY, J., The effect of loading rate and temperature on the initiation of fracture in a mild, rate-sensitive steel. Trans. ASTM. J. Eng. Mater. Tech., 1979, 101, pp258-264.

[8] A0KI, S., Dynamic fracture mechanics and dynamic fracture toughness. J. Soc. Mater. Sci. JAPAN, 1987, 36, 402, pp274-279. 